\title{
Study of Bryophytic Flora in the Ramsar Wetland of Merja Zerga (North-west of Morocco)
}

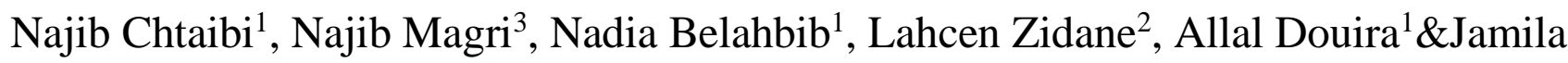 \\ Dahmani $^{1^{*}}$
}

${ }^{1}$ Laboratory of Botany, Biotechnology and Plant Protection, Faculty of Science, Ibn Tofail University, BP 133, Kénitra 14000, Morocco

${ }^{2}$ Laboratory of Biodiversity and Plant Resources, Faculty of Science, Ibn Tofail University, BP 133, Kénitra 14000, Morocco ${ }^{3}$ Forest Research Center, High Commission for Water, Forests and Desertification Control, Avenue Omar Ibn El Khattab, BP 763 , Rabat-Agdal, 10050, Morocco

\begin{abstract}
The research undertaken in the IBA and Ramsar wetland of Merja Zerga at Moulay Bousselham were interested only in the higher plants. Our study tends then to contribute to enrich the knowledge about the bryophytic flora of this area by filling the gaps in this field. Thus, we carried out a systematic sampling with a stop and a harvest in each encountered bryophyte population. This prospection enabled us to find 26 species of bryophytes including 22 species of mosses belonging to 15 genera and 9 families, and 4 species of liverworts belonging to 3 genera and 3 families. The relative low specificity of this wetland can be explained by the influence of sea spray and the strong anthropic disturbance. A comparison with previous studies allowed us to conclude that 11 species were observed for the first time in the area.
\end{abstract}

Keywords-Biodiversity,Bryophytes,IBA and Ramsar Wetland, Merja Zerga, Morocco.

\section{INTRODUCTION}

Wetlands are among the ecosystems that have been subject to frequent scientific studies. These studies have highlighted these areas and their undeniable role in biogeochemical cycles, especially the water cycle. In Morocco, 38 wetlands are classified as Biological and Ecological Interest Site (BEIS) in the continental domain and 38 wetlands as BEIS in the coastal area (CEIBM, 2016). Among them, 20 are designated as Important Bird Areas (IBA) and 24 as Ramsar Wetlands; Merja Zergaour study area- is part of both IBA (Interest Biodiversity Area) and Ramsar (Cherkaoui\& al., 2015).

Moroccan wetlands, despite conservation efforts, have undergone considerable deterioration that still increasing (Dakki and El Hamzaoui, 1998). According to Hammada et al. (2004), the natural drought, which was very frequent and severe for decades, made the situation far worse.
Water consumption has continued to increase, while water reserves are steadily declining. The frequent drying of habitats throughout the country is compounded by an increase in the salinity of coastal wetlands that are largely invaded by marine waters because of climate change.

Merja Zerga, a wetland listed in the coastal area, is a populated and popular site because of its proximity to the touristic and recreational site of MoulayBousselhame. It copes then with an abusive exploitation such as overgrazing, excessive cutting of reeds that lead to habitat loss (Hammada et al., 2004). Benabid (2000) and Cherkaoui\& al. (2015) state that in bird nesting period, the destruction of biotopes of multiplication of avifauna can involve a major disturbance in the life cycles.

According to Dakki and El Hamzaoui (1998), we can distinguish five plant formations from the south of the lagoon to the surrounding dunes: algae and eelgrass, Spartinadensiflora formation, Salicornia halophilous grasslands, Juncusrigidushalophilous grasslands and low lawn. At Drader River, submerged fresh water vegetation (Myriophyllum, Potamogeton) marks the passage between the lagoon and the fresh waters.

Considered as the most important transit point in Morocco for ducks and other migratory birds (Benabid, 2000), this zone was subject to studies that were interested in the phanerophyte or algal flora (Hammada et al., 2004), but no specific research has been carried out on the bryological flora. The objective of this study is therefore to contribute to the inventory of the species of the bryophytes of Merja Zerga in order to fill the gaps in knowledge.

\section{MATERIALS AND METHODS}

\subsection{Description}

Merja Zerga is a wetland belonging to the Gharb basin. It is bounded to the north by Drader River, which drains a 
watershed of $1150 \mathrm{~km}^{2}$, leads in the lagoon at the end of the main canal and at the delta in the northeastern part of Merja Zerga (Figure 1). In the south, the Nador Canal, built in 1953, drains the M'da watershed over $700 \mathrm{~km}$ as well as the right bank of Sebou River (Lamrini et al., 2007). Benhoussa et al. (1999) report that, in addition to Atlantic and continental influence, the freshwater aquifer that levels in several points of the wetland is not negligible.

The lagoon has an elliptical shape and is located at the northwest of the Kingdom of Morocco (34 $51^{\prime}$ North, $6^{\circ} 16^{\prime}$ West). It is composed of two Merjas: MerjaKahla of $3 \mathrm{~km}^{2}$ in the north with a depth lower than $50 \mathrm{~cm}$ at high tide and Merja Zerga of $27 \mathrm{~km}^{2}$, with a $9 \mathrm{~km}$ of length and $5 \mathrm{~km}$ of width (Snoussi and Raji, 2011).

Geologically, Merja Zerga is located between the Atlantic Ocean in the west, the Rif mountains in the north and the Atlantic Meseta at the north-western end of Rharb Basin; it occupies a synclinal flexion of tectonic origin. Two categories of sediment line the lagoon: vases coming from the contributions of Drader River and the Nador Canal in the calm zones and sands of essentially marine origin in the main canal area and at the pass (Bidet, 1977).

According to Gam (2008), the region is under a climate of Mediterranean type subject to oceanic influences; the mean temperature is of $18^{\circ} \mathrm{C}$ with an important annual thermal variation $\left(26^{\circ} \mathrm{C}\right)$. The Merja Zerga lagoon is subjected to micro to mesotidal regime with a tidal range of 0.15 to $1.5 \mathrm{~m}$ (Carruesco, 1989).

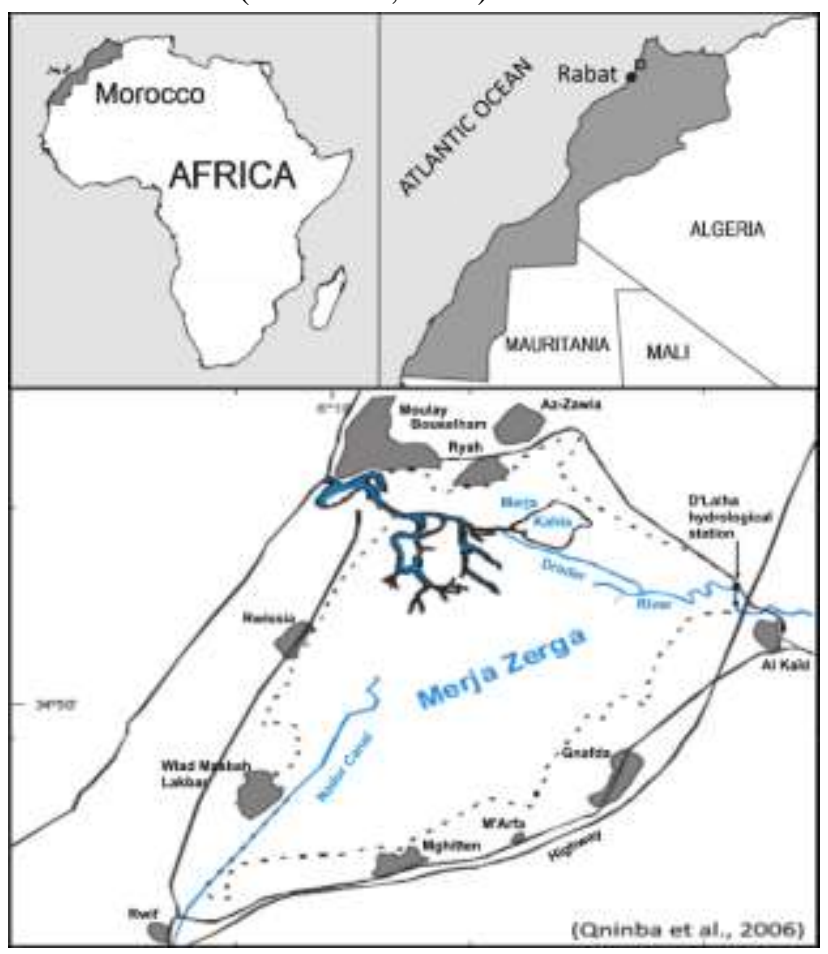

Fig.1: Geographical location (top right) and general physiognomy of MerjaZerga (Qninba et al., 2006 with modifications)
Salinity varies according to seasons and tides. In summer, it can go up to $35 \mathrm{psu}$; In winter and due to freshwater inputs, it fluctuates between 27 and 30 psu (Labbardi et al., 2005).

Plant groups in the area can be organized by Phragmites communis, Scirpuslacustris, Iris pseudacorus, Salicornia arabica, S. perennis, Juncusacutus, J. subulatus (Benabid, 2000).

\subsection{Work Method}

We adopted the systematic sampling: we stopped at each encountered stand and we collect a sample there, taking care not to pick up the entire population in order to preserve the species. Each time we geolocated the waypoint by a GPS tool.

The samples are carefully placed in plastic boxes with a label indicating the date, the number of the sample, the type of substrate and its moisture level evaluated according to the closest water. The identification of the samples was carried out on the basis of morphological, anatomical and histological criteria. We used the following determination keys: Augier (1966); Pierrot (1982) and Smith (2004).

For each species, we have kept a sample in herbarium for later potential verifications.

\section{RESULTS AND DISCUSSION}

\subsection{Recorded species of bryophytes}

The identification of the bryophytes of Merja Zerga allowed us to establish a list of 26 species belonging to 9 families (Fig.2).

The family of Pottiaceae is represented by 6 species: BarbulafallaxHedw., 1801, Barbulaunguiculata (Huds) Hedw., 1801, Timmiella barbuloides Brid., 1927, Tortella flavovirens (Bruch) Broth., 1902, TortulamuralisHedw., 1801, Trichostomumbrachydontium Bruch., 1829. For the family of Brachytheciaceae, we found these 5 species: Brachytheciumcollinum (Schleich.) B.e., 1853, Brachytheciumvelutinum (Hedw.) B.e., 1853, Brachytheciumstarkei (Brid.) B.e., 1853, Platyhypnidiumriparioides (Hedw.) Dixon, 1934, Rhynchostegiummegapolitanum (Bland.) B.e., 1852). The Bryaceae are represented by 3 species: BryumargenteumHedw., 1801, BryumcapillareHedw., 1801, Bryumpseudotriquetrum (Hedw.) Schwaegr., 1802) and the Orthotrichaceae by 2 species: Orthotrichum affineSchrad., 1801 and Orthotrichumdefluens Vent., 1882. The family of Funariaceae includes 2 species: FunariaHygrometricaHedw., $1801 \quad$ and Entosthodontempletonii (Sm.) Schwaegr., 1832. Finaly, the families of Grimmiaceae, Leucodontaceae, Fissidentaceae and Dicranaceae are represented each one by a single species, respectively: 
GrimmiaalpestrisSchleich., 1807, Leucodonsciuroides (Hedw.) Schwägr.,1816, FissidenspolyphyllusWils., 1851 and Dicranellasubulata (Hedw.) Schimp., 1856.

The liverworts are represented by only 3 families (Figure 2): Ricciaceae with 2 species (Ricciaciliifera Link, et R.
sorocarpaBisch) and Lunulariaceae and Targioniaceae, with one species for each, respectively: Lunulariacruciata (Linnaeus) Dum., 1829 and Targioniahypophylla L., 1753.

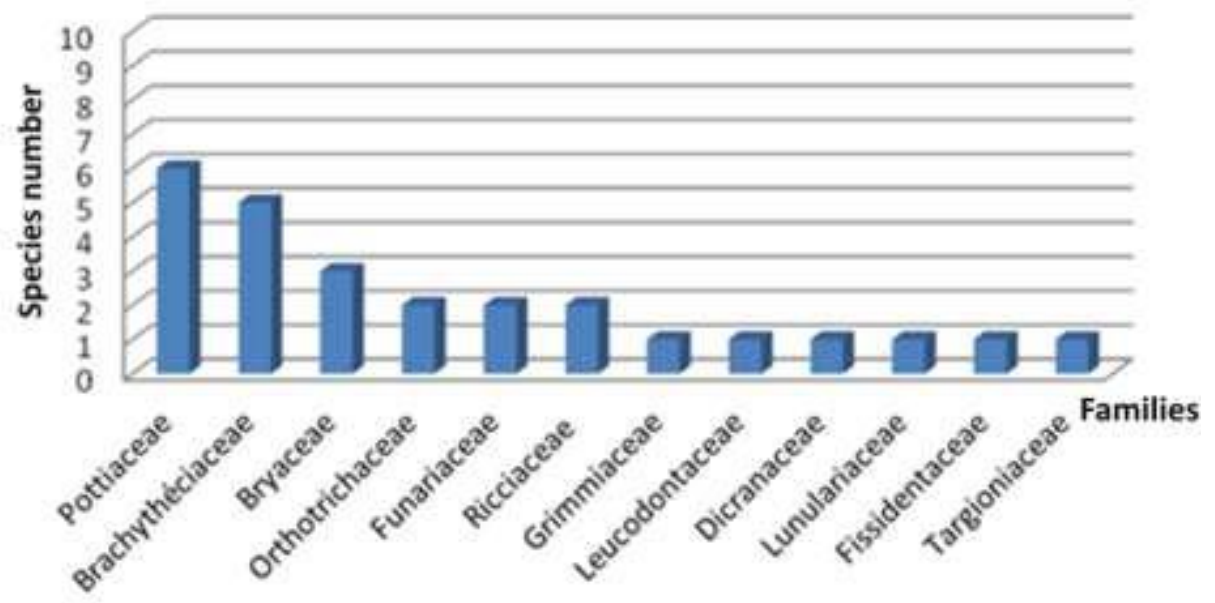

Fig.2: Distribution of families of bryophytes according to their species richness

According to Hosni et al. (2010), the lagoon's waters are contaminated by mineral pollutants coming from about 6 000 hectares of irrigated perimeters that discharge their drainage waters through the Nador Canal and the Drader River.

According to Ayadi (2013), the amount of pesticides applied to the different crops in Merja Zerga territory is $138666 \mathrm{~kg}$ over an area of nearly $39050 \mathrm{ha}$, so an overall average of $3.6 \mathrm{~kg} / \mathrm{ha}$. This quantity is large enough to explain the low specific richness of bryophytes in the area. In fact, pesticides, especially herbicides applied to crops, are subject to runoff and leaching and this pollution would limit floristic biodiversity in general and bryological biodiversity in particular.

Moreover, the sandy soil, low in organic matter and rich in salt, can only allow the installation of a specific vegetation adapted to this type of environment. This vegetation is mainly nitrophilic due to the important anthropic activities around the Merja and halophilic due to the salt richness of the environment.

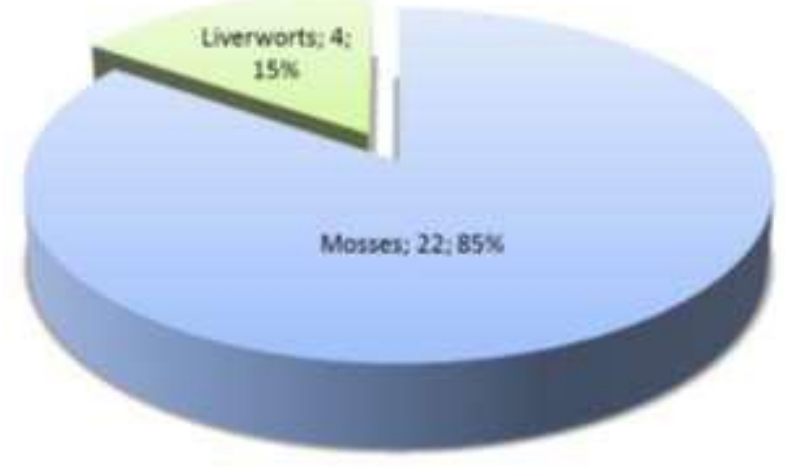

Fig.3: Distribution of bryophytes species in the study area

Otherwise, the results show that mosses are the most represented with $85 \%$ of the identified species, followed by liverworts with only $15 \%$ (Fig.3). We have not found any Anthocerotes species.

We found 7 species on moist soil that remains waterlogged for much of the year: Platyhypnidiumriparioides (Hedw.) Dixon.,Rhynchostegiummegapolitanum (Bland.) B.e., FissidenspolyphyllusWils.,Ricciaciliifera Link., RicciasorocarpaBisch., Targioniahypophylla L., Leucodonsciuroides (Hedw.) Schwägr., and Entosthodontempletonii (Sm.) Schwaegr. On the contrary, we found just 5 species on dry soils that are only moistened during rainy days: TrichostomumbrachydontiumBruch.,Brachytheciumcollin um (Schleich.) B.e., Dicranellasubulata (Hedw.) Schimp., and Brachytheciumstarkei (Brid.) B.e. The remaining mentioned species can be found in all types of environments.

We have noted that some species have a relatively high abundance, case

of BarbulafallaxHedw.,Barbulaunguiculata (Huds) Hedw., TortulamuralisHedw., Timmiella barbuloides Brid., Tortella flavovirens (Bruch) Broth., Brachytheciumvelutinum (Hedw.) B.e., BryumargenteumHedw., BryumcapillareHedw., GrimmiaalpestrisSchleich., Lunulariacruciata (Linnaeus) Dum., Orthotrichum affineSchrad., Orthotrichumdefluens Vent., FunariaHygrometricaHedw., and Bryumpseudotriquetrum (Hedw.) Schwaegr. Others 
species have a relatively low abundance such as Brachytheciumstarkei

(Brid.)

Platyhypnidiumriparioides

Rhynchostegiummegapolitanum Leucodonsciuroides (Hedw.) Schwägr., and RicciasorocarpaBisch. The remaining species are of medium abundance.

The species found in the eucalyptus forest which borders MerjaZerga are Platyhypnidiumriparioides (Hedw.) Dixon., Leucodonsciuroides (Hedw.) Schwägr., FissidenspolyphyllusWils., Entoosthodontempletonii. (Sm.) Schwaegr., Trichostomumbrachydontium Bruch., Brachytheciumcollinum (Schleich. Dicranellasubulata (Hedw.) Schimp., Brachytheciumstarkei (Brid.) B.e., BarbulafallaxHedw., Barbulaunguiculata (Huds) Hedw., TortulamuralisHedw., Timmiella barbuloidesBrid.,

$\begin{array}{lr}\text { Brachytheciumvelutinum } & \text { (Hedw.) B.e., Bryum } \\ \text { capillareHedw., } & \text { GrimmiaalpestrisSchleich., }\end{array}$
Orthotrichum affineSchrad., Orthotrichumdefluens Vent. andFunariaHygrometricaHedw.

\subsection{The new species for the region}

We compared our findings with the inventory of bryophytes (Ahayoun et al., 2007, 2013) and we noticed that 11 species were encountered for the first time in Merja Zerga (Fig.4). The new species are BarbulafallaxHedw.,Brachytheciumcollinum (Schleich.) B.e., Brachytheciumvelutinum (Hedw.) B.e., Platyhypnidiumriparioides

(Hedw.) Dixon.,BryumargenteumHedw. Bryumpseudotriquetrum (Hedw.) Schwaegr.,GrimmiaalpestrisSchleich., Leucodonsciuroides (Hedw.) Schwägr.,Orthotrichum affineSchrad., Dicranellasubulata (Hedw.) Schimp. andOrthotrichumdefluens Vent.

Tortella

flavovirens

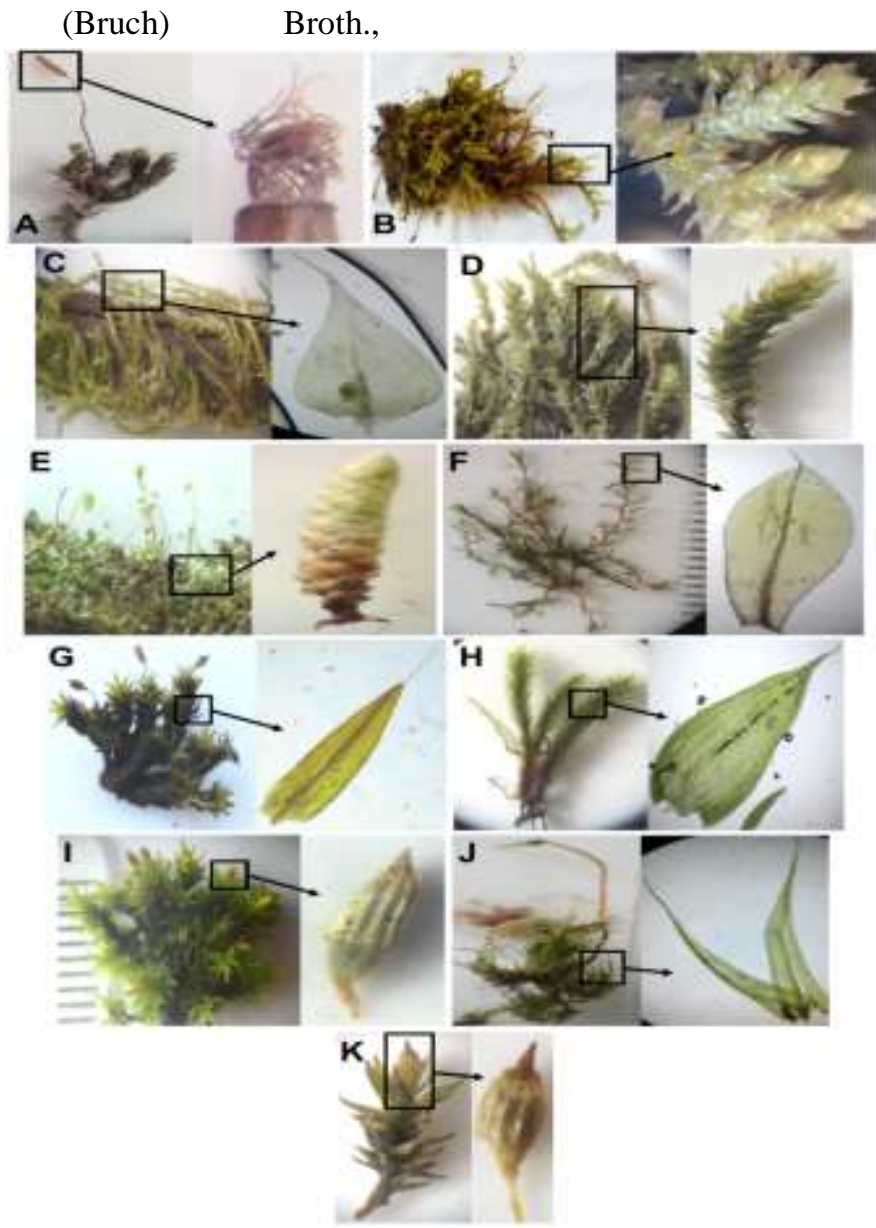

Fig.4: Species newly encountered in the study area: (a) BarbulafallaxHedw., complete sample on the left, Capsule with peristome $x 4.5$ and zoom $x 2$ on the right; (b) Brachytheciumcollinum (Schleich.) B.e. with moistened branches showing concave leaves $x 100$ on the right; (c) Brachytheciumvelutinum (Hedw.) B.e. on the left, leaf x100 on the right; (d) Platyhypnidiumriparioides (Hedw.) Dixon. with moistened branch on the left; (e) BryumargenteumHedw. with moistened branch on the left x100; (f) Bryumpseudotriquetrum (Hedw.) Schwaegr. with a leaf x100 on the right ; $(g)$ GrimmiaalpestrisSchleich., a capsule on the left and a leaf on the right; (h) Leucodonsciuroides (Hedw.) Schwägr. with a leaf $x 100$ on the right ; (i) Orthotrichum affine Schrad., a capsule with peristome on the right; (j) Dicranellasubulata (Hedw.) Schimp. with a leaf on the right x100; ( $k$ ) Orthotrichumdefluens Vent., a capsule with peristome on the right. 


\section{CONCLUSION}

Our study carried out in the Ramsar wetland of Merja Zerga allowed us to note the presence of 26 species of bryophytes including 22 species of mosses belonging to 16 genera and 9 families, and 4 species of liverworts belonging to 3 genera and 3 families. The mosses represent $85 \%$ of the identified species while the liverworts are only $15 \%$.

Over the 26 listed species, 11 were encountered for the first time in the study area. These new cited species are BarbulafallaxHedw., Brachytheciumcollinum (Schleich.) B.e., Brachytheciumvelutinum (Hedw.) B.e., Platyhypnidiumriparioides (Hedw.) Dixon.,BryumargenteumHedw. Bryumpseudotriquetrum (Hedw.) Schwaegr.,GrimmiaalpestrisSchleich., Leucodonsciuroides (Hedw.) Schwägr.,Orthotrichum affineSchrad., Dicranellasubulata (Hedw.) Schimp. andOrthotrichumdefluens Vent.

We noticed a weak specific richness in the zone that we can explain by the fact that the environment is under the influence of sea spray and subjected to strong anthropic pressure.

\section{REFERENCES}

[1] K. AHAYOUN, A. OUAZZANI TOUHAMI, M. FENNANE \&A. DOUIRA, 2007- Inventaire des Bryophytes de l'Herbier 'RAB' de l'Institut Scientifique (Rabat, Maroc), Documents de l'Institut Scientifique, Rabat, $21: 71-88$.

[2] K. AHAYOUN. A. OUAZZANI TOUHAMI. R. BENKIRANE\&A. DOUIRA, 2013 - Catalogue bibliographique des Bryophytes du Maroc (19132011). Journal of Animal \& Plant Sciences, 17(1) : 2433-2513.

[3] H. AYADI-HAJJI, 2013 - Outils de gestion de la pollution phytosanitaire diffuse au niveau d'un territoire : cas d'application à la zone humide RAMSAR de la Merja Zerga au Maroc. Thèse de Doctorat, Universite Paul-Valéry, Montpellier 3 et IAV Hassan II Rabat, 364 p.

[4] A.BENABID, 2000 - Flore et écosystèmes du Maroc, évaluation et préservation de la biodiversité. Ed. Ibis Presse, Paris, $360 \mathrm{p}$.

[5] J.C. BIDET, 1977 - Un milieu sédimentaire actuel : la lagune de Moulay Bousselham (côte atlantique marocaine). Bulletin de l'Institut de géologie du bassind'Aquitaine (Bordeaux), 22 : 189-230.

[6] A. BENHOUSSA, M. DAKKI, A. QNINBA etM. EL AGBANI, 1999 - Habitats d'un site RAMSAR, côtier du Maroc, la Merja Zerga: approches typologique et cartographique, HumedalesMediterráneos, SEHUMED, Valencia (España), pp. 75-76.
[7] C. CARRUESCO, 1989 - La lagune de Moulay Bousselham (Côte atlantique, Maroc), un environnement côtier artificiel. Sciences Géologiques Memorandum, pp. 145-158.

[8] S.I. CHERKAOUI, S. HANANE, N. MAGRI, M.A. EL AGBANI \&M. DAKKI, 2015. - Factors Influencing Species-Richness of Breeding Waterbirds in Moroccan IBA and Ramsar Wetlands: A Macroecological Approach. Wetlands (2015) volume 35 number 5, pp. 913-922.

[9] M. DAKKI \&M. EL HAMZAOUI, 1998- Les zones humides du Maroc : Rapport National. Adm. Eaux \& Forêts Cons. Sols, Bur Ramsar \& Med. Wet., 31 p.

[10] M. GAM, 2008 - Dynamique des systèmes parasites hôte, entre trématodes digenes et coque Cerastodermaedule: comparaison de la lagune de Merja Zerga avec le bassin d'Arcachon. Thèseencotutelle, Univ. Hassane II et Université de Bordeau, $207 \mathrm{p}$.

[11] S. HAMMADA, M. DAKKI, M. IBN TATTOU, A. OUYAHYA \&M. FENNANE, 2004 - Analyse de la biodiversité floristique des zones humides du Maroc. Flore Rare, Menacée Et Halophile. Acta Botanica Malacitana, 29 : 43-66.

[12] K. HOSNI, Z. BENDAHHOU, M. ROBIN, A. AAJJANE, 2010 - Contamination de la lagune de Moulay Bousselham par les deux affluents Oued Drader et Canal Nador (Résultats préliminaires). Colloque Eau, Déchets et Développement Durable, 28 - 31 mars 2010, Alexandrie, Egypte, pp. 123-130

[13] H.LABBARDI, O. ETTAHIRI, S. LAZAR, Z. MASSIK, S. EL ANTRI, 2005 - Etude de la variation spatiotemporelle des paramètres physico-chimiques caractérisant la qualité des eaux d'une lagune côtière et ses zonations écologiques : cas de Moulay Bousselham, Maroc. ComptesRendus de Géoscience, pp. 504-5144.

[14]M. LACOSTE, 1984 - Contribution à l'étude écologique de la lagune de Moulay Bousselham (Maroc). Thèse de doctorat, Université Paul Sabatier, Toulouse, $207 \mathrm{p}$.

[15] A. LAMRINI, H. ARID, J. MEZIANE, 2007Contribution à l'étude du potentiel aquacole de la lagune de Moulay Bousselham (Maroc) à l'aide de la télédétection et d'un système d'information géographique. Télédétection, $7: 111-127$.

[16] R.B.Pierrot,1982- Les Bryophytes du CentreOuest. Bulletin de la Société Botanique du CentreOuest. $\mathrm{N}^{\circ}$ spécial $5.61 \mathrm{p}$.

[17]A. QNINBA, A. BENHOUSSA, M. EL AGBANI, M. DAKKI, M. THEVENOT, 2006 - Etude phénologique et variabilité interannuelle d'abondance des Charadriidés (Aves, Charadrii) dans un site 
RAMSAR du Maroc : la Merja Zerga. Bulletin de l'InstitutScientifique, section Sciences de la Vie, 28 : 35-47.

[18] A.J.E. Smith, 2004- The Moss Flora of Britain and Ireland. Cambridge UniversityPress, Cambridge. $1024 \mathrm{p}$.

[19] M.SNOUSSI, O. RAJI, 2011- La lagune Moulay Bousselham - Maroc. Equipe de recherche Environnement Côtiers \& Changement Climatique (E3C), Université Mohamed V Rabat, Maroc, 1 p.

[20] Centre d'Échange d'Information sur la Biodiversité du Maroc, 2016. A Moroccan Biodiversity Information Exchange website. The Clearing House of Morocco (CHM) on biodiversity. http://ma.chmcbd.net/, accessed on 15 December 2016. 